\title{
Identification of gamma ray irradiation-induced mutations in membrane transport genes in a rice population by TILLING
}

\author{
Jung Eun Hwang ${ }^{1,2}$, Duk-Soo Jang ${ }^{3}$, Kyung Jun Lee ${ }^{4}$, Joon-Woo Ahn ${ }^{1}$, Sang Hoon Kim ${ }^{1}$, \\ Si-Yong Kang ${ }^{1}$, Dong Sub Kim ${ }^{5}$ and Jin-Baek Kim ${ }^{1 *}$ \\ ${ }^{1}$ Advanced Radiation Technology Institute, Korea Atomic Energy Research Institute (KAERI), Jeongeup 580-180, \\ Republic of Korea \\ ${ }^{2}$ Division of Ecological Conservation, Bureau of Ecological Research, National Institute of Ecology, \\ 1210 Geumgang-ro, Seocheon 33657, Republic of Korea \\ ${ }^{3}$ Animal and Plant Quarantine Agency, 177 hyeoksin 8-ro, Gimcheon-si, Gyeongsangbuk-do, \\ 39660, Republic of Korea \\ ${ }^{4}$ National Agrobiodiversity Center, NAAS, RDA, Jeonju 560-500, Republic of Korea \\ ${ }^{5}$ NJ Biopia Co. Ltd., 672 Haseo-ro, Gwangju 500-260, Republic of Korea
}

(Received 29 July 2015, accepted 6 April 2016; J-STAGE Advance published date: 1 September 2016)

A high-salt environment represents environmental stress for most plants. Those that can grow and thrive in such an environment must have membrane transport systems that can respond effectively. Plant roots absorb $\mathrm{Na}^{+}$from the soil, and the plant must maintain $\mathrm{Na}^{+}$homeostasis to survive salt stress. A major mechanism by which salt-tolerant plants adapt to salt stress is through modulation of ion transport genes. We have subjected a population of rice plants to mutagenesis, and identified lines with both single-nucleotide polymorphisms (SNPs) in membrane transport genes and altered responses to salt stress. Primers labeled with FAM or HEX fluorescent dyes were designed for nine target genes encoding membrane transport proteins that are believed to regulate salt stress tolerance. A TILLING (Targeting Induced Local Lesions IN Genome) assay was performed on $2,961 \mathrm{M}_{2}$ rice mutant lines using electrophoresis. After the TILLING assay, a total of 41 mutant lines containing SNPs in the target genes were identified and screened. The average number of mutations per gene was $1 / 492 \mathrm{~kb}$ in lines having SNPs, and the percentage of mutation sites per total sequence was 0.67. Among the 41 lines, nine had altered sequences in the exon region of the genes. Of these nine lines, seven were tolerant to salt stress after exposure to $170 \mathrm{mM} \mathrm{NaCl}$ for three weeks, while the other two lines were not more salt-tolerant than the control lines. Furthermore, five mutant lines containing SNPs in the coding region of OsAKT1, OsHKT6, OsNSCC2, OsHAK11 and OsSOS1 showed changed expression levels for each gene. We conclude that variation in membrane transport genes, such as expression levels and protein structures, may affect the rice plant's tolerance to salt stress. These mutations represent traits that may be selected for large rice mutant populations, permitting efficient acquisition of salt-tolerant lines.

Key words: gamma rays, membrane transport system, mutation, rice, salt tolerance

\section{INTRODUCTION}

Saline soils negatively affect plant growth and production, primarily through osmotic stress and toxicity of high

Edited by Koji Murai

* Corresponding author. E-mail: jbkim74@kaeri.re.kr

DOI: http://doi.org/10.1266/ggs.15-00052 ion concentrations, predominantly $\mathrm{Na}^{+}$and $\mathrm{Cl}^{-}$(Munns and Tester, 2008; Wan, 2011). Salinity currently limits crop productivity worldwide, with almost 900 million ha of saline soils across the globe (Flowers, 2004). Of the cereal crops, rice (Oryza sativa) is the most salt-sensitive. When exposed to a salinity increase of $1 \mathrm{dS} \mathrm{m} \mathrm{m}^{-1}$ beyond the threshold of $3.0 \mathrm{dS} \mathrm{m} \mathrm{m}^{-1}$, rice yield decreased by $12 \%$ (Chinnusamy et al., 2006; Munns and Tester, 
2008). This illustrates the importance of developing salttolerant rice varieties to increase food production in the face of a growing human population and global climate change.

The ability of plants to grow in high salt is associated with their ability to maintain ion homeostasis by limiting $\mathrm{Na}^{+}$uptake and by sequestering $\mathrm{Na}^{+}$and $\mathrm{Cl}^{-}$into vacuoles (Cheong and Yun, 2007; Munns and Tester, 2008; Kronzucker and Britto, 2011). In particular, membrane transport proteins act as a shuttle for intracellular and extracellular ions such as $\mathrm{Na}^{+}, \mathrm{Ca}^{2+}$ and $\mathrm{K}^{+}$(Møller and Tester, 2007; Kronzucker and Britto, 2011). For example, the gene $S K C 1$, which encodes an HKT-type transporter that regulates $\mathrm{K}^{+} / \mathrm{Na}^{+}$homeostasis in shoots, enhanced salt tolerance in the indica rice variety Nona Bokra (Ren et al., 2005). Polymorphisms in the coding region of SKC1 between Nona Bokra and a susceptible rice cultivar affected SKC1 expression level and salt tolerance (Ren et al., 2005). In Arabidopsis thaliana, a plasma membrane $\mathrm{Na}^{+} / \mathrm{H}^{+}$antiporter, AtSOS1, mediates efflux of excess $\mathrm{Na}^{+}$ions and contributes to $\mathrm{Na}^{+}$detoxification (Shi et al., 2002); the rice antiporter OsSOS1 has been shown to be a functional homolog of AtSOS1 (MartínezAtienza et al., 2007). In addition, vacuolar $\mathrm{Na}^{+} / \mathrm{H}^{+}$antiporters are responsible for compartmentalizing $\mathrm{Na}^{+}$into vacuoles to maintain a low $\mathrm{Na}^{+}$concentration (Fukuda et al., 2011). Fukuda et al. (1999) cloned a vacuolar $\mathrm{Na}^{+} /$ $\mathrm{H}^{+}$antiporter gene, OsNHX1, from Oryza sativa L. cv. Nipponbare, a salt-sensitive cultivar, and showed that its overexpression improved the salt tolerance of transgenic rice plants (Fukuda et al., 2004; Chen et al., 2007).

Conventional breeding to develop saline-tolerant rice has consisted of screening its germplasm, both in the field and in hydroponic culture. Since 1970, the International Rice Research Institute has screened approximately 100,000 varieties for salt tolerance and identified a number of tolerant varieties, including Pokkali, Getu and Nona Bokra (Negrão et al., 2011). The Chinese Academy of Agricultural Science selected approximately 100 salt-tolerant varieties from 3,000 varieties in China $(\mathrm{Hu}$ et al., 2012). In addition to conventional breeding, lines with enhanced saline tolerance have been generated by mutation. Nakhoda et al. (2012) identified four tolerant rice mutant lines from about 5,000 diepoxybutane $\mathbf{M}_{4}$ mutant lines using hydroponic screening at the seedling stage. These salt-tolerant rice mutants produced a yield that was comparable to that produced by the IR64 variety when they were grown under normal conditions, but produced an average of approximately $0.8-1.0 \mathrm{t} \mathrm{ha}^{-1}$ greater yield than IR64 when the two were grown in saline fields (Nakhoda et al., 2012). Salt-tolerant mutant lines have also been acquired by using gamma irradiation to induce mutation and combining it with in vitro culture (Lang and Buu, 2008).

Besides forward selection from mutant lines, a reverse genetic approach such as Targeting Induced Local Lesions IN Genomes (TILLING) is useful for rapid selection for salt tolerance from mutant populations. Since their first application in A. thaliana in 2000, TILLING assays have been used for screening mutants in many other crops (Till et al., 2007; Suzuki et al., 2008; Dierking and Bilyeu, 2009; Minoia et al., 2010). A key advantage of high-throughput TILLING is that the position of the mutation in target genes can be inferred from fragment size detected through an enzyme cutting at the mutation site. Furthermore, double-end-labeling with a fluorescent primer combined with a capillary electrophoresis system and Dye 700 and Dye 800 provided high-throughput and accurate size detection that was superior to an agarose gel system (Henikoff et al., 2004).

In this study, we have generated salt-tolerant rice mutants with gamma irradiation. We report results of the high-throughput TILLING method with a capillary electrophoresis system that was used to identify DNA polymorphisms of membrane transport genes that confer salt tolerance in the mutant population.

\section{MATERIALS AND METHODS}

Plant materials and genomic DNA extraction Ten thousand seeds (5,000 per treatment) of $O$. sativa cv. Dongan were irradiated with 200 or 300 Gy from a ${ }^{60} \mathrm{Co}$ gamma irradiator (maximum output, 150 TBq; ACEL, Nordion, Ottawa, Canada) at the Korea Atomic Energy Research Institute. After irradiation, the seeds were sowed in soil, surviving seedlings ( $M_{1}$ plants) were cultured in a paddy field, and the panicles $\left(\mathrm{M}_{2}\right.$ seeds $)$ in each $\mathrm{M}_{1}$ plant were harvested. One seed from each panicle was planted as an $\mathrm{M}_{2}$ plant. Of these, 1,620 $\mathrm{M}_{2}$ plants derived from $300 \mathrm{~Gy}$ and 1,341 $\mathrm{M}_{2}$ plants derived from 200 Gy were used in a TILLING experiment.

Genomic DNA was extracted from a leaf from each of the 2,961 $\mathrm{M}_{2}$ lines. The leaf was ground using FastPrep (MP Biomedicals, Irvine, CA, USA) in a manufacturer-provided tube filled with a DNeasy 96 plant extraction kit (Qiagen, Hilden, Germany), centrifuged, and the upper part of each column was transferred to a new E-tube. The amount of DNA in $2 \mu \mathrm{l}$ of the solution in the new tube was quantified with a spectrophotometer (ND-1000, Wilmington, DE, USA) and adjusted to a concentration of $15 \mathrm{ng} / \mu \mathrm{l}$.

\section{Mutation screening using a modified TILLING} method First, we wished to locate the site of mutations that had been generated by the irradiation. DNA pools from the 2,961 $\mathrm{M}_{2}$ lines were screened for mutations in nine membrane transport genes by the TILLING method. All DNA pools were amplified with PCR primers specific for these gene sequences. A total of nine primer sets were designed, one for each gene, which comprised exon and intron regions in various chromosomes (Table 
1). For detection of the peak deduced by capillary electrophoresis, forward and reverse primers designed as a PCR amplification set were labeled with the fluorescent dyes FAM and HEX, respectively.

For clear amplification of the target region, a touchdown PCR method was used under the following conditions: ini- tial denaturing at $95{ }^{\circ} \mathrm{C}$ for 5 min, 15 cycles of touchdown PCR $\left(95^{\circ} \mathrm{C}\right.$ for $30 \mathrm{sec}$, an annealing step starting at 58-62 ${ }^{\circ} \mathrm{C}$ for each primer set for $30 \mathrm{sec}$ and then decreasing by $0.4{ }^{\circ} \mathrm{C}$ per cycle, and $72{ }^{\circ} \mathrm{C}$ for $60 \mathrm{sec}$ ), and 30 additional cycles of PCR $\left(95{ }^{\circ} \mathrm{C}\right.$ for $30 \mathrm{sec}, 52-56{ }^{\circ} \mathrm{C}$ for $30 \mathrm{sec}$, and 72 ${ }^{\circ} \mathrm{C}$ for $\left.60 \mathrm{sec}\right)$. After PCR amplification, the PCR products

Table 1. PCR primer sets for amplifying target regions and real-time PCR in membrane transport genes

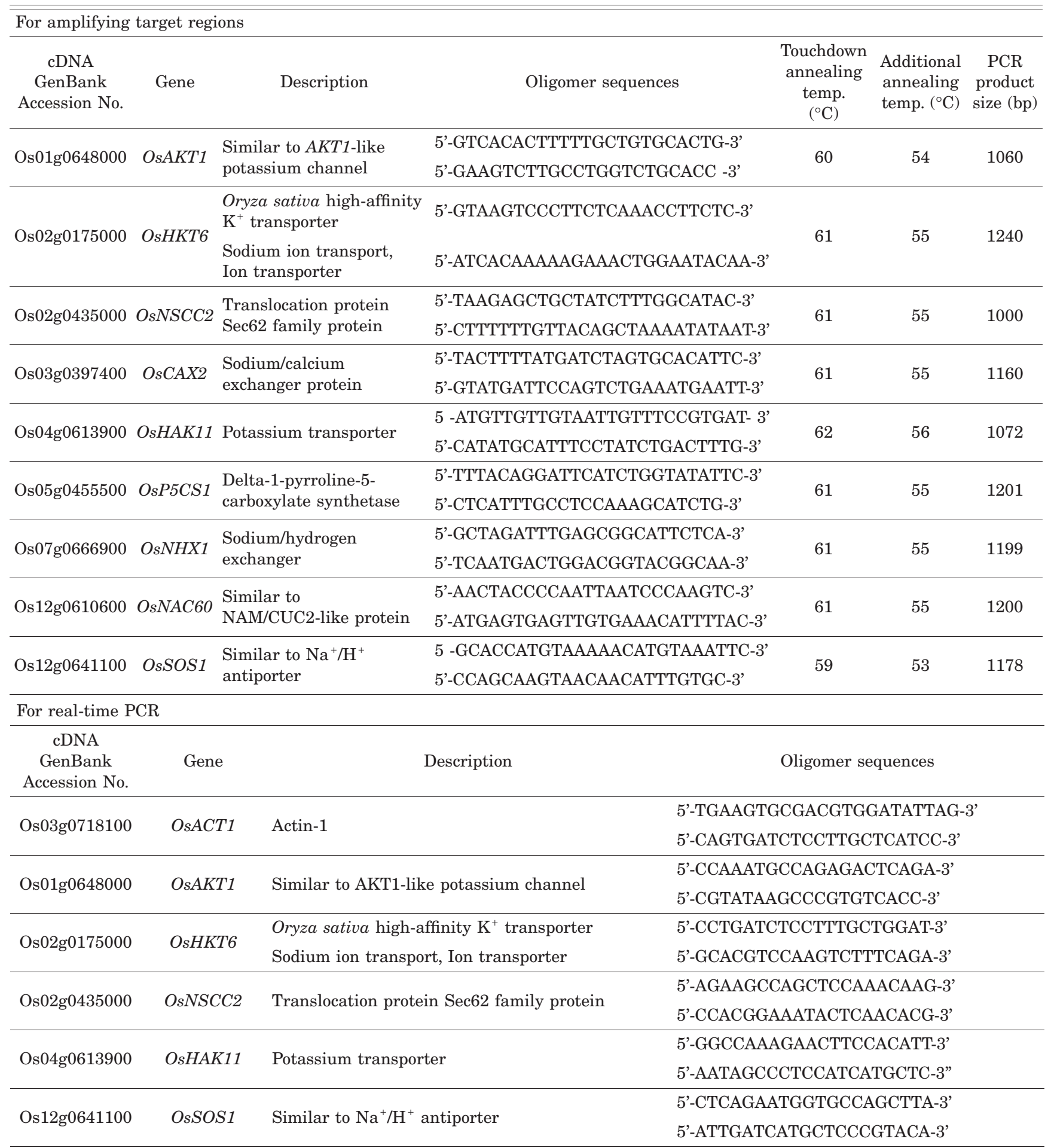


were exposed to various temperatures to allow heteroduplex formation in the thermocycler: the temperature was set at $95{ }^{\circ} \mathrm{C}$ and $80{ }^{\circ} \mathrm{C}$ for $5 \mathrm{~min}$ to denature the doublestranded DNA and inactivate the Taq polymerase, and then set at $75{ }^{\circ} \mathrm{C}$ for $10 \mathrm{~min}, 60{ }^{\circ} \mathrm{C}$ for $10 \mathrm{~min}, 40{ }^{\circ} \mathrm{C}$ for $20 \mathrm{~min}$ and $25^{\circ} \mathrm{C}$ for $20 \mathrm{~min}$ to anneal the denatured DNA strands. The re-annealed PCR products were digested at $42{ }^{\circ} \mathrm{C}$ for $20 \mathrm{~min}$ in $12 \mu \mathrm{l}$ enzyme solution containing 10 $\mu \mathrm{l}$ of PCR products, $0.3 \mu \mathrm{l}$ of CEL1, $0.3 \mu \mathrm{l}$ of enhancer and $1.4 \mu \mathrm{l}$ of a $1 \times$ PCR buffer (Takara), and CEL1 activity was stopped by adding $1.5 \mu \mathrm{l}$ of stop solution (Transgenomic, Omaha, NE, USA). For electrophoresis, $3 \mu \mathrm{l}$ of each cleaved product was placed into each well of a MicroAmp 96-well plate (Thermo Fisher Scientific, Waltham, MA, USA) with $7.5 \mu \mathrm{l} \mathrm{Hi-Di} \mathrm{formamide} \mathrm{(Thermo} \mathrm{Fisher} \mathrm{Sci-}$ entific) and $0.5 \mu \mathrm{l}$ ROX size standard. The mixture was denatured at $95{ }^{\circ} \mathrm{C}$ for $5 \mathrm{~min}$ and incubated on ice until it was mounted on the capillary electrophoresis plate. The products were analyzed using ABI 3130XL capillary electrophoresis. To output the analysis data, Peak Scanner software v1.0 (Thermo Fisher Scientific) was used with the default amplified fragment length polymorphism method.

Detection of SNPs It is important to confirm that the SNP site in the target gene corresponds to the results from the capillary electrophoresis. To this end, selected mutant lines from the TILLING analysis were sequenced with specific primers. The sequencing analysis was conducted using BigDye Terminator v3.1 (ABI) with ABI 3130XL capillary electrophoresis. The sequence data of the selected mutant lines were aligned with the corresponding seguences of cv. Dongan using ClustalW (http:// www.clustalw.com) to detect the SNPs.

Phenotype confirmation For the seedling growth test, seeds were sown on 1/2 MS medium containing Murashige and Skoog salts (Duchefa, Haarlem, Netherlands), 3\% sucrose and $0.3 \%$ gelite (Duchefa), with or without 170 $\mathrm{mM} \mathrm{NaCl}$, and grown under a $16 \mathrm{~h}$ light/8 h dark cycle at $24{ }^{\circ} \mathrm{C}$. Ten seedlings were chosen from each dish for determinations of root and shoot length at three weeks after sowing.

Statistical analysis Data were subjected to one-way ANOVA. The mean values for ten replicate samples were compared using Duncan's multiple range test. Differences were considered significant at $P \leq 0.05$.

Quantitative RT-PCR analysis Seven selected mutant lines were grown in medium containing $170 \mathrm{mM} \mathrm{NaCl}$ for two weeks, and total RNA was isolated using TRIzol reagent according to the manufacturer's protocol (Gibco BRL, Cleveland, OH, USA). Next, $1 \mu \mathrm{g}$ of total RNA was used as a template for reverse transcription using a Power cDNA Synthesis Kit (Intron Biotechnology,
Sungnam, Korea) for $60 \mathrm{~min}$ at $42{ }^{\circ} \mathrm{C}$ with $1 \mu \mathrm{g}$ oligo(dT)15 primers. The synthesized cDNAs were used as templates for quantitative RT-PCR, which was performed on the Eco Real-Time PCR system (Illumina, San Diego, CA, USA) using SYBR Premix Ex Taq (Takara). The PCR thermal cycle conditions were $95{ }^{\circ} \mathrm{C}$ for $10 \mathrm{~min}$, followed by 45 cycles of $95{ }^{\circ} \mathrm{C}$ for $10 \mathrm{sec}$ and $60{ }^{\circ} \mathrm{C}$ for $30 \mathrm{sec}$. The primer sequences are listed in Table 1. The OsACT1 (Os03g0718100) gene was used as the internal control (Hwang et al., 2014b).

\section{RESULTS}

Generation of gamma-irradiated rice mutant populations Rice mutant lines were generated by irradiating seeds of cv. Dongan with 200 and 300 Gy. Because phenotypes associated with recessive mutations could be identified in the $M_{2}$ generation, $M_{1}$ plants were harvested in bulk. In the $\mathrm{M}_{2}$ generation, we selected 2,961 mutant lines with excellent agricultural characteristics, including rice yield factors and growth habits, and used them in a TILLING experiment.

Identification of mutations by the TILLING method Eight-fold pools of genomic DNA from leaf tissues of $\mathrm{M}_{2}$

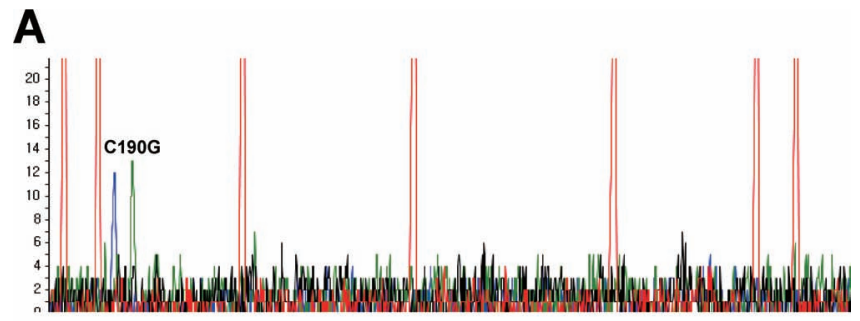

\section{B}

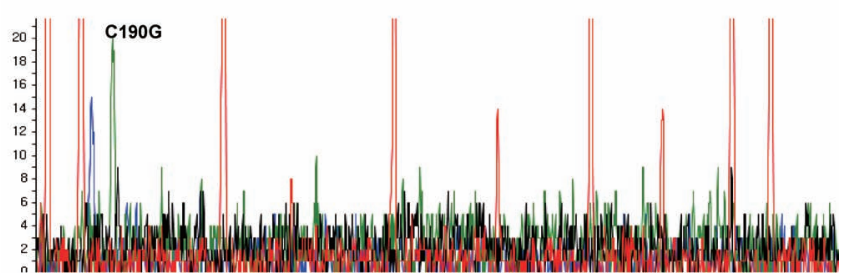

Fig. 1. Results of the detection of SNPs by capillary electrophoresis after amplification with $O s C A X 2$ primer. An example is shown of the results acquired by comparing peak data from the capillary electrophoresis with the DNA sequencing alignment data in 2,961 mutant lines. The SNPs were detected differently in the mutant lines according to each fluorescent primer set. A and $\mathrm{B}$ indicate the peaks of the pooled data and are the results from a two-dimensional pool: (A) is composed of the DNA from the lines Till-III-1155, -1167, -1179, -1191, -1203, -1215, -1227 and -1239 , while (B) consists of the lines Till-III-1179, -1180, -1181, $-1182,-1183,-1184,-1185$ and -1186 . Because the two pools in (A) and (B) both include Till-III-1179, Till-III-1179 could have SNP. 
Table 2. Mutations discovered in the mutant rice population in this study, using the TILLING method

\begin{tabular}{|c|c|c|c|c|c|c|c|}
\hline Target gene & $\begin{array}{l}\text { Mutation line } \\
\quad \text { (detected } \\
\text { fluorescence) }\end{array}$ & $\begin{array}{l}\text { PCR } \\
\text { product } \\
\text { size }\end{array}$ & $\begin{array}{l}\text { Expected SNP } \\
\text { site from } \\
\text { capillary } \\
\text { electrophoresis }\end{array}$ & $\begin{array}{c}\text { Calculated SNP } \\
\text { site from } \\
\text { capillary } \\
\text { electrophoresis }\end{array}$ & $\begin{array}{l}\text { Detected SNP } \\
\text { site from } \\
\text { sequencing } \\
\text { alignment }\end{array}$ & $\begin{array}{c}\text { Changed } \\
\text { base }\end{array}$ & $\begin{array}{l}\text { Mutation } \\
\text { frequency }\end{array}$ \\
\hline$O s A K T 1(\mathrm{R})$ & Till-III-19 (FAM) & 1060 & 170 & 890 & 908 & $\mathrm{~A} \rightarrow \mathrm{G}$ & $1 / 3139 \mathrm{~kb}$ \\
\hline \multirow{9}{*}{$O s H K T 6(\mathrm{~F})$} & Till-II-724 (FAM) & 1240 & 380 & 380 & 348 & $\mathrm{G} \rightarrow \mathrm{A}$ & \multirow{9}{*}{$1 / 408 \mathrm{~kb}$} \\
\hline & Till-II-780 (FAM) & 1240 & 161 & 161 & 192 & $\mathrm{~A} \rightarrow \mathrm{G}$ & \\
\hline & Till-II-864 (FAM) & 1240 & 160 & 160 & 192 & $\mathrm{~A} \rightarrow \mathrm{G}$ & \\
\hline & Till-II-871 (FAM) & 1240 & 356 & 356 & 383 & $\mathrm{G} \rightarrow \mathrm{C}$ & \\
\hline & Till-II-969 (FAM) & 1240 & 161 & 161 & 192 & $\mathrm{~A} \rightarrow \mathrm{G}$ & \\
\hline & Till-II-970 (FAM) & 1240 & 160 & 160 & 192 & $\mathrm{~A} \rightarrow \mathrm{G}$ & \\
\hline & Till-II-1062 (FAM) & 1240 & 162 & 162 & 192 & $\mathrm{~A} \rightarrow \mathrm{G}$ & \\
\hline & Till-III-43 (FAM) & 1240 & 160 & 160 & 192 & $\mathrm{~A} \rightarrow \mathrm{G}$ & \\
\hline & Till-III-324 (FAM) & 1240 & 495 & 495 & 500 & $\mathrm{G} \rightarrow \mathrm{T}$ & \\
\hline \multirow{10}{*}{ OsNSCC2(R) } & Till-II-775 (FAM) & 1000 & 210 & 790 & 793 & $\mathrm{C} \rightarrow \mathrm{G}$ & \multirow{10}{*}{$1 / 296 \mathrm{~kb}$} \\
\hline & Till-II-787 (FAM) & 1000 & 212 & 788 & 793 & $\mathrm{C} \rightarrow \mathrm{G}$ & \\
\hline & Till-II-847 (FAM) & 1000 & 211 & 789 & 793 & $\mathrm{C} \rightarrow \mathrm{G}$ & \\
\hline & Till-II-776 (FAM) & 1000 & 221 & 779 & 793 & $\mathrm{C} \rightarrow \mathrm{G}$ & \\
\hline & Till-II-788 (FAM) & 1000 & 198 & 802 & 793 & $\mathrm{C} \rightarrow \mathrm{G}$ & \\
\hline & Till-II-848 (FAM) & 1000 & 200 & 800 & 793 & $\mathrm{C} \rightarrow \mathrm{G}$ & \\
\hline & Till-III-114 (FAM) & 1000 & 355 & 645 & 663 & $\mathrm{C} \rightarrow \mathrm{T}$ & \\
\hline & Till-III-142 (FAM) & 1000 & 355 & 645 & 663 & $\mathrm{C} \rightarrow \mathrm{T}$ & \\
\hline & Till-III-255 (FAM) & 1000 & 355 & 645 & 663 & $\mathrm{C} \rightarrow \mathrm{T}$ & \\
\hline & Till-II-301 (FAM) & 1000 & 565 & 435 & 435 & $\mathrm{~A} \rightarrow \mathrm{G}$ & \\
\hline \multirow{8}{*}{$O s C A X 2(\mathrm{~F})$} & Till-II-279 (FAM) & 1160 & 193 & 193 & 190 & $\mathrm{C} \rightarrow \mathrm{G}$ & \multirow{8}{*}{$1 / 429 \mathrm{~kb}$} \\
\hline & Till-II-406 (FAM) & 1160 & 223 & 223 & 190 & $\mathrm{C} \rightarrow \mathrm{G}$ & \\
\hline & Till-II-785 (HEX) & 1160 & 230 & 930 & 940 & $\mathrm{~T} \rightarrow \mathrm{C}$ & \\
\hline & Till-III-203 (FAM) & 1160 & 355 & 355 & 402 & $\mathrm{G} \rightarrow \mathrm{A}$ & \\
\hline & Till-III-325 (FAM) & 1160 & 178 & 178 & 190 & $\mathrm{C} \rightarrow \mathrm{G}$ & \\
\hline & Till-III-459 (FAM) & 1160 & 355 & 355 & 402 & $\mathrm{G} \rightarrow \mathrm{A}$ & \\
\hline & Till-III-1179 (FAM) & 1160 & 164 & 164 & 190 & $\mathrm{C} \rightarrow \mathrm{G}$ & \\
\hline & Till-III-1378 (FAM) & 1160 & 165 & 165 & 190 & $\mathrm{C} \rightarrow \mathrm{G}$ & \\
\hline \multirow{3}{*}{ OsHAK11(R) } & Till-III-955 (HEX) & 1072 & 537 & 537 & 537 & $\mathrm{G} \rightarrow-$ & \multirow{3}{*}{$1 / 1058 \mathrm{~kb}$} \\
\hline & Till-II-1160 (FAM) & 1072 & 1013 & 59 & 53 & $\mathrm{~A} \rightarrow-$ & \\
\hline & Till-II-1196 (FAM) & 1072 & 1002 & 70 & 53 & $\mathrm{~A} \rightarrow-$ & \\
\hline \multirow{2}{*}{ OsP5CS1(R) } & Till-III-191 (FAM) & 1201 & 380 & 821 & 773 & $\mathrm{~A} \rightarrow \mathrm{T}$ & \multirow{2}{*}{$1 / 1778 \mathrm{~kb}$} \\
\hline & Till-III-196 (HEX) & 1201 & 390 & 390 & 415 & $\mathrm{~A} \rightarrow \mathrm{G}$ & \\
\hline$O s N H X 1(\mathrm{~F})$ & 0 & 1199 & - & - & - & - & 0 \\
\hline \multirow{5}{*}{ OsNAC60(F) } & Till-II-985 (FAM) & 1200 & 221 & 221 & 245 & $\mathrm{~A} \rightarrow \mathrm{C}$ & \multirow{5}{*}{$1 / 711 \mathrm{~kb}$} \\
\hline & Till-II-1106 (FAM) & 1200 & 469 & 469 & 469 & $\mathrm{CG} \rightarrow \mathrm{TT}$ & \\
\hline & Till-II-1173 (FAM) & 1200 & 256 & 256 & 261 & $\mathrm{~A} \rightarrow \mathrm{T}$ & \\
\hline & Till-III-157 (FAM) & 1200 & 355 & 355 & 326 & $\mathrm{~A} \rightarrow \mathrm{G}$ & \\
\hline & Till-III-572 (FAM) & 1200 & 178 & 178 & 188 & $\mathrm{G} \rightarrow \mathrm{T}$ & \\
\hline \multirow{3}{*}{ OsSOS1(F) } & Till-III-1028 (FAM) & 1178 & 288 & 288 & 323 & $\mathrm{C} \rightarrow \mathrm{T}$ & \multirow{3}{*}{$1 / 1163 \mathrm{~kb}$} \\
\hline & Till-III-1224 (FAM) & 1178 & 310 & 310 & 322 & $\mathrm{~T} \rightarrow \mathrm{C}$ & \\
\hline & Till-III-1431 (FAM) & 1178 & 290 & 290 & 311 & $\mathrm{G} \rightarrow \mathrm{A}$ & \\
\hline Total & 41 & & & & & GC-AT $(58 \%)$ & $1 / 658 \mathrm{~kb}$ \\
\hline
\end{tabular}



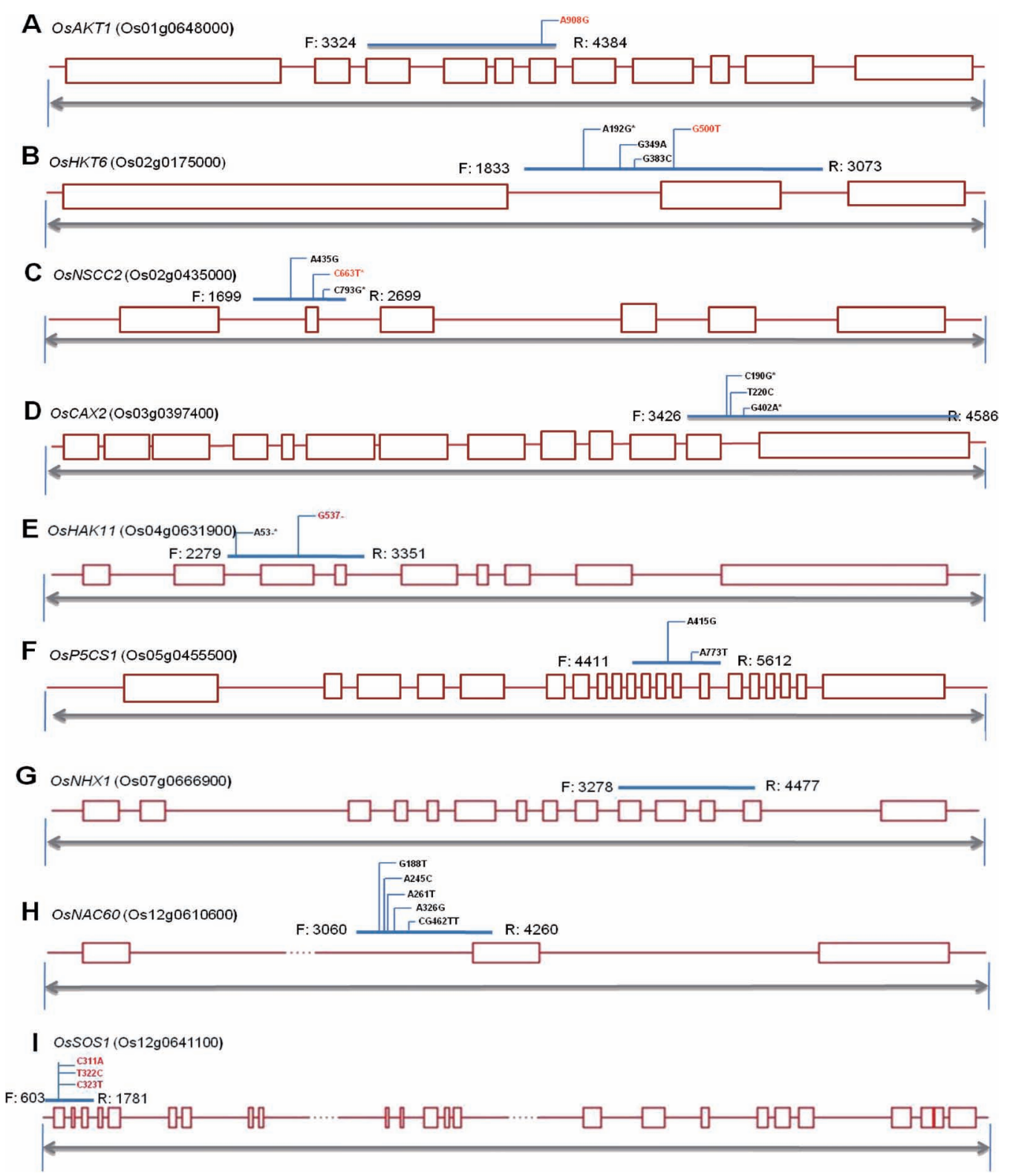

Fig. 2. Positions of SNPs detected in each target gene. Horizontal blue lines indicate amplified regions of the target genes and there are various SNPs within these blue lines. The positions of the SNPs and the phase of the mutated sequence are marked with a number and letters, respectively. Rectangular red boxes represent exons of the genes and the red letters indicate SNPs located within exons. An asterisk indicates the position of SNPs commonly detected in more than one line.

Table 3. Summary of the amino acid changes identified in mutations within coding regions

\begin{tabular}{|c|c|c|c|c|c|}
\hline $\begin{array}{l}\text { cDNA GenBank } \\
\text { Accession No. }\end{array}$ & Gene & Nucleotide change & Exon & $\begin{array}{l}\text { Predicted } \\
\text { AA change }\end{array}$ & Line \\
\hline Os01g0648000 & OsAKT1 & A908G & E6 & $\mathrm{V} \rightarrow \mathrm{C}$ & Till-III-19 \\
\hline Os02g0175000 & OsHKT6 & G500T & E2 & $\mathrm{I} \rightarrow \mathrm{L}$ & Till-III-324 \\
\hline Os02g0435000 & OsNSCC2 & C663T & E2 & $\mathrm{A} \rightarrow \mathrm{V}$ & Till-III-114, Till-III-142, Till-III-255 \\
\hline Os04g0631900 & OsHAK11 & G537- & E3 & $\mathrm{N} \rightarrow-$ & Till-III-955 \\
\hline \multirow[t]{3}{*}{ Os12g0641100 } & OsSOS1 & G311A & E1 & Silent & Till-III-1224 \\
\hline & & $\mathrm{T} 322 \mathrm{C}$ & E1 & $\mathrm{S} \rightarrow \mathrm{P}$ & Till-III-1224 \\
\hline & & C323T & E1 & Silent & Till-III-1224 \\
\hline
\end{tabular}


plants were used for TILLING. The membrane transport system involves many different types of genes which play key roles in the salt tolerance of plants. For the TILLING screening, nine genes involved in membrane transport for ion homeostasis were selected, based on our unpublished microarray data of rice treated with salt stress: OsAKT1 (Obata et al., 2007), OsHKT6 (Garciadeblás et al., 2003), OsNSCC2 (Demidchik and Tester, 2002, http://ricephy-
Non-treated
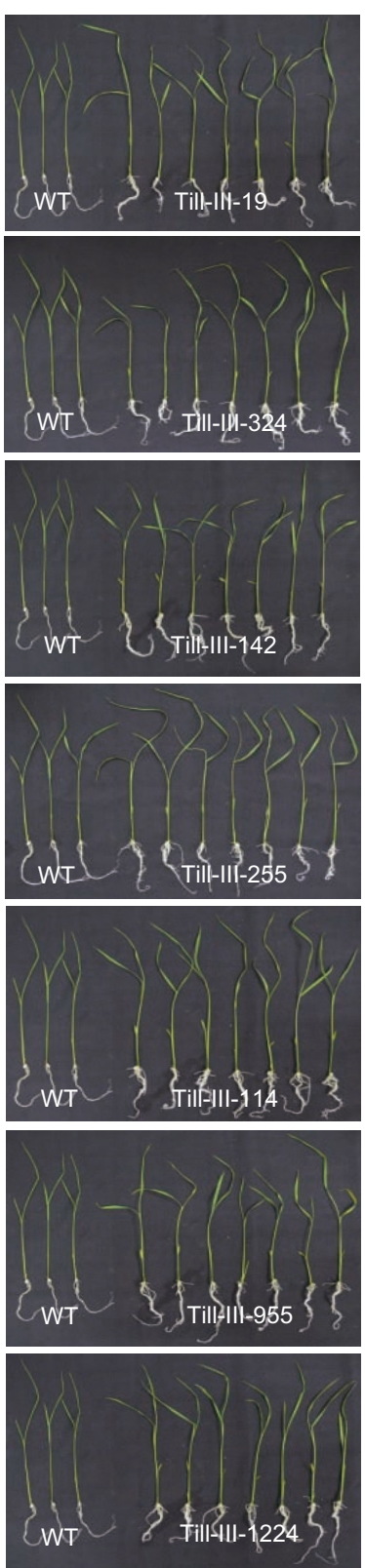

$\mathrm{NaCl}(170 \mathrm{mM})$
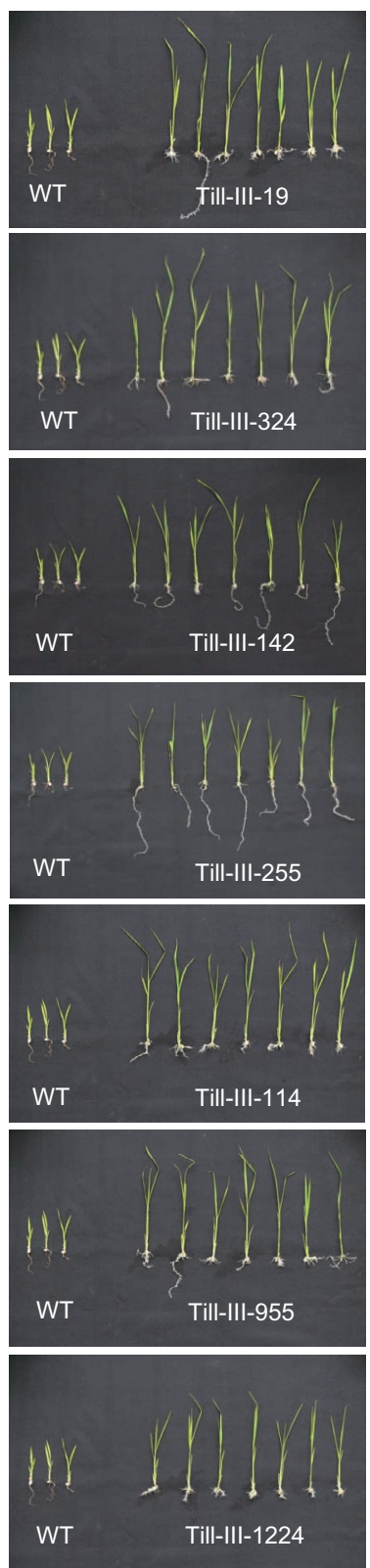

Fig. 3. Phenotype of the salt-tolerant lines. The phenotypes of wild-type (WT) (cv. Dongan) plants and the salt-tolerant lines containing SNPs in membrane transport genes were compared. SNPs were identified by TILLING and salt tolerance was tested by exposing the seven mutant lines and the WT to $170 \mathrm{mM}$ $\mathrm{NaCl}$ for three weeks in vitro. logenomics.ucdavis.edu/ transporter), OsCAX2 (Kimiya et al., 2005; Yamada et al., 2014), OsHAK11 (Okada et al., 2008), OsP5CS1 (Hur et al., 2004), OsSOS1 and OsNHX1 (Fukuda et al., 2011), and OsNAC60 (Fang et al., 2008). Previous studies reported that all the selected genes are related to the transportation of ions such as $\mathrm{Na}^{+}$(Yokoi et al., 2002; Munns and Tester, 2008; Hussain et al., 2010). The annotations of the target genes are summarized as follows: OsAKT1 is the channel for the movement of potassium; OsHKT6 is an ion transporter, a high-affinity $\mathrm{K}^{+}$transporter, and a sodium ion transporter in O. sativa; OsNSCC2 is a translocation protein; $O s C A X 2$ is a low-affinity calcium transporter; OsHAK11 is a potassium uptake protein and a KUP domain-containing protein; OsP5CS1 catalyzes a rate-limiting step of proline biosynthesis; OsNHX1 is a $\mathrm{Na}^{+} / \mathrm{H}^{+}$ion change antiporter like NHX6; OsNAC60 is a NAM/CUC2-like protein; and OsSOS1 is similar to a $\mathrm{Na}^{+} / \mathrm{H}^{+}$antiporter. For detection of radiation-induced SNPs, we used the target gene primers listed in Table 1 . With nine target genes to be analyzed, the pooled DNA samples were divided into 10 replicates from the mother pool and a total of 80 plates were amplified by PCR. Figure 1 shows the results of analysis with Peak Scanner software v1.0. X-Rhodamine (ROX)-labeled size standards (red peaks in the figure) serve as markers, so that the positions of the cut peaks are analyzed approximately, and the base-pair positions and concentrations can be determined using the information obtained by clicking on the cut peaks. A capillary electrophoresis analysis of the sets of eight pooled samples produced profiles A (a pool containing Till-III-1155, -1167, $-1179,-1191,-1203,-1215,-1227$ and -1239) and B (a pool containing Till-III-1179, -1180, -1181, -1182, -1183, -1184, -1185 and -1186) (Fig. 1); both represent different dimensions. The peak data of $\mathrm{A}$ and $\mathrm{B}$ were then matched to

Table 4. Germination rate, root length and shoot length of WT and mutant plants with and without salt stress

\begin{tabular}{|c|c|c|c|c|}
\hline & \multicolumn{2}{|c|}{ Root length $(\mathrm{cm})$} & \multicolumn{2}{|c|}{ Shoot length $(\mathrm{cm})$} \\
\hline & Non-treated & Treated & Non-treated & Treated \\
\hline Wild-type & $11.1 \pm 0.9^{\mathrm{NS}}$ & $2.97 \pm 1.0$ & ${ }^{\mathrm{b}} 22.57 \pm 2^{\mathrm{b}}$ & $3.57 \pm 0.2^{\mathrm{e}}$ \\
\hline Till-III-19 & $7.43 \pm 2.7$ & $2.63 \pm 6.2$ & ${ }^{\mathrm{b}} 22.54 \pm 4^{\mathrm{b}}$ & $13.4 \pm 4.6^{\mathrm{abc}}$ \\
\hline Till-III-324 & $9.96 \pm 7.7$ & $2.53 \pm 2.7$ & ${ }^{\mathrm{b}} 21.84 \pm 4.1^{\mathrm{b}}$ & $16.63 \pm 5.6^{c}$ \\
\hline Till-III-142 & $8.87 \pm 3.5$ & $8.84 \pm 1.2$ & $20.01 \pm 4^{\mathrm{b}}$ & $14.66 \pm 2.1^{\mathrm{ab}}$ \\
\hline Till-III-255 & $7.67 \pm 1.7$ & $8.93 \pm 3.7$ & ${ }^{\mathrm{a}} 31.46 \pm 5.6^{\mathrm{a}}$ & $7.84 \pm 1.8^{d}$ \\
\hline Till-III-114 & $9.06 \pm 1.1$ & $1.74 \pm 2.4$ & ${ }^{\mathrm{b}} 23.34 \pm 2.7^{\mathrm{b}}$ & $15.53 \pm 3.1^{\mathrm{a}}$ \\
\hline Till-III-955 & $9.56 \pm 2$ & $2.96 \pm 4.3$ & b $20.6 \pm 6.6^{\mathrm{b}}$ & $14.76 \pm 3.5^{\mathrm{ab}}$ \\
\hline Till-III-1224 & $49.47 \pm 2$ & $1.47 \pm 0.8$ & ${ }^{\mathrm{b}} 21.1 \pm 2.8^{\mathrm{b}}$ & $12.57 \pm 1.6^{\mathrm{bc}}$ \\
\hline \multicolumn{5}{|c|}{$\begin{array}{l}\text { Values are mean } \pm \mathrm{SE} \text { based on } 10 \text { replicates }(\mathrm{n}=10) \text { for length. } \\
\mathrm{a,b,c,d, \textrm {e }} \text { : Values with different superscript letters are significantly } \\
\text { different from each other at } P \leq 0.05 \text { according to Duncan's } \\
\text { multiple range test. } \\
\text { NS: Not significant. }\end{array}$} \\
\hline
\end{tabular}


each other. Because pools A and B both contained the mutant line Till-III-1179, this indicates that -1179 possesses a SNP. In the sequencing analysis, we confirmed
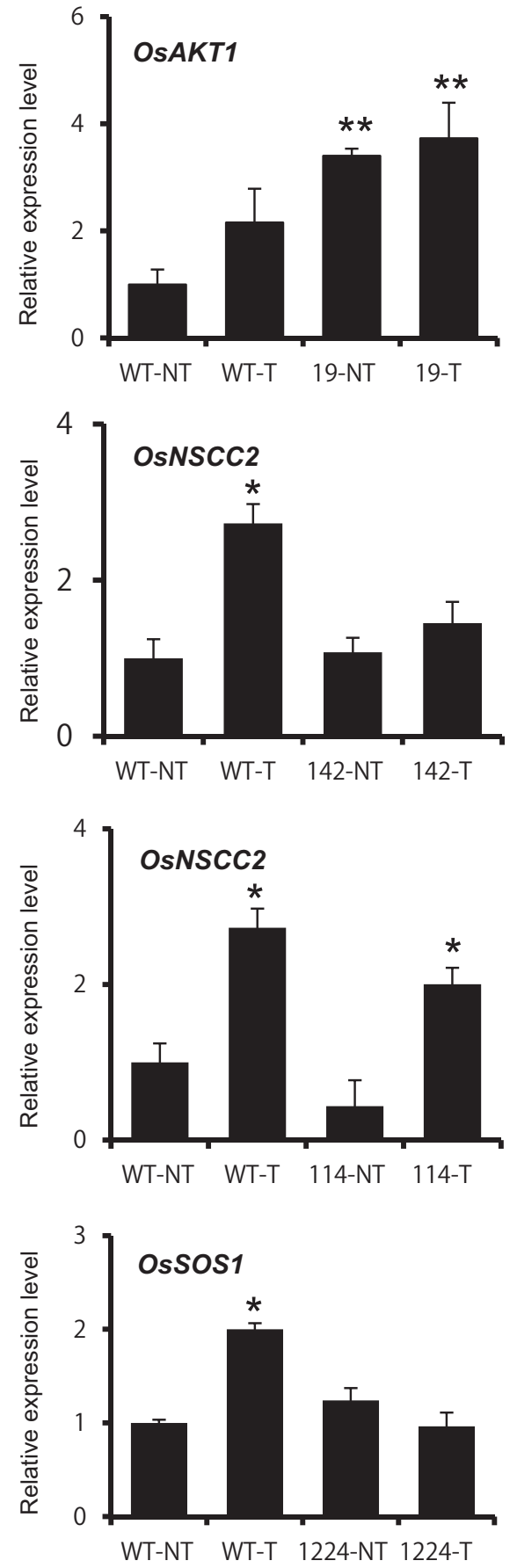

the SNP (C190G) in Till-III-1179 compared with the original cultivar. We can conclude from the results with the Till-III-1179 line that the 190th base in the target region
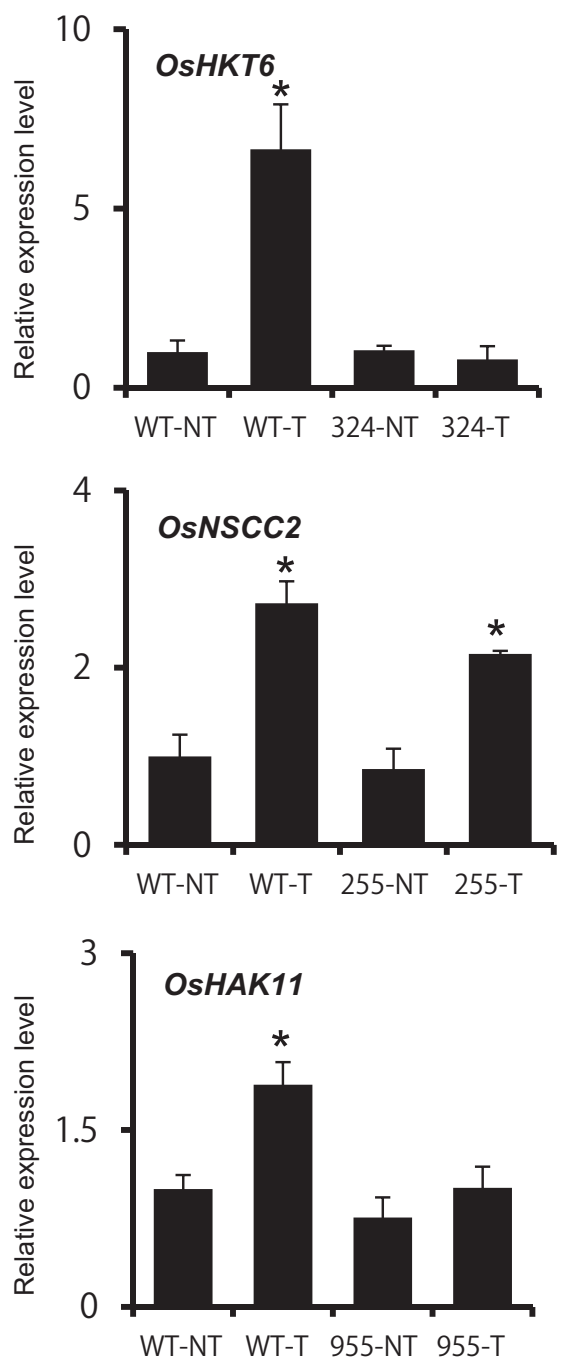

Fig. 4. Quantification of membrane transport gene transcripts in each mutant line by real-time PCR. Expression profiles of five membrane transport genes (OsAKT1, OsHKT6, OsNSCC2, OsHAK11 and OsSOS1) in seven SNPcontaining mutants are shown. mRNA level was normalized to that of the ACT1 transcript and expressed as a ratio relative to the value of OsACT1 mRNA in non-treated WT. NT, non-treated; T, salt-treated $(170 \mathrm{mM} \mathrm{NaCl})$; WT, wild-type (cv. Dongan); 19, Till-III-19; 324, Till-III-324; 142, Till-III-142; 255, Till-III-255; 114, Till-III-114; 955, Till-III-955; 1224, Till-III-1224. Double asterisks $\left(^{* *}\right)$ denote significant differences in transcript level between WT and Till-III-19 under salt-treated or non-treated conditions $(P<0.05)$. Single asterisks $(*)$ denote significant differences in transcript level in response to salt treatment (comparison between samples in the same line with and without salt treatment; $P<0.05$ ). The data represent the mean \pm standard deviation from triplicate experiments. 
of the $\mathrm{OsCAX2}$ gene was mutated from $\mathrm{C}$ to $\mathrm{G}$.

Identification of SNPs in membrane transportrelated genes SNPs, identified using capillary electrophoresis analysis and DNA sequence alignment, were detected in all nine target genes, and 41 lines were selected from a total of 2,961 $\mathrm{M}_{2}$ plants (Table 2). The number of lines with SNPs in particular genes was variable. Ten lines were selected with SNPs in OsNSCC2, while only one line had an SNP in OsAKT1. No lines were found with SNPs in OsNHX1 (Table 2). An unusual phenomenon was observed with respect to OsHKT6, OsNSCC2 and OsCAX2: lines with SNPs in the same position were present in these genes. It may be, then, that plant-specific nucleotide sequences have regions sensitive to radiation that are prone to mutation and, therefore, SNPs.

To confirm the mutation in the cleaved products, PCR fragments from both wild-type and mutant lines were sequenced. The sequences of the nine membrane transport genes from 41 mutant lines revealed that 70 SNPs were located in exon and intron regions of these genes (Table 2). Sequence mutations occurred at different frequencies in different genes: OsHKT6, OsNSCC2 and OsCAX2 had the highest frequency of mutation, with one mutation per $408 \mathrm{~kb}, 296 \mathrm{~kb}$ and $429 \mathrm{~kb}$, respectively. OsP5CS1 had the lowest sequence mutation frequency, with one mutation per $1,778 \mathrm{~kb}$. The average frequency was one mutation per $658 \mathrm{~kb}$ (Table 2). Figure 2 shows the position of the SNPs in each gene. They were evenly spaced in OsHKT6 and OsHAK11, while OsSOS1 had SNPs concentrated in certain sites. Rectangular red boxes in Fig. 2 represent the exons of the genes and the red letters represent SNPs located within exons. Nine lines had SNPs in exons: Till-III-19 in OsAKT1; Till-III-324 in OsHKT6; Till-III-114, Till-III-142 and Till-III-255 in OsNSCC2; Till-III-955 in OsHAK11; and Till-III-1028, Till-III-1224 and Till-III-1431 in OsSOS1 (Table 2). Among the mutations in exons, C111A in Till-III-1028 and C123T in TillIII-1431 of OsSOS1 were silent and G537- of OsHAK11 in Till-III-955 was a mis-sense mutation (Table 3). Three of the lines had mutations at the $663 \mathrm{bp}$ position in $\mathrm{OsN}$ $S C C 2$, with a C-to-T transition that caused an amino acid change from A to $\mathrm{V}$ (Table 3).

Phenotyping the selected mutant lines The next step was to determine whether the mutations in the target genes resulted in salt-tolerant phenotypes. Plants from each of the nine lines with SNPs in exons were selected and supplied with $170 \mathrm{mM} \mathrm{NaCl}(1 \% \mathrm{NaCl})$ for three weeks. Seven of the mutant lines (Till-III-19, -324, -142, $-255,-114,-955$ and -1224$)$ showed a salt stress-tolerant phenotype (Fig. 3), whereas the other two lines had phenotypes similar to the wild-type (data not shown). To quantify the growth effect under salt stress, we compared root and shoot length of the seven salt-tolerant lines (Table 4) with those of the wild-type (cv. Dongan). Plant growth was reduced by the saline treatment, as measured by these lengths (Table 4). The effect of saline on growth was greater in the wild-type than in the mutants (Table 4). These results suggest that the mutation of membrane transport-related genes affects salt stress tolerance. For the selection of salt tolerance in rice, it is necessary to understand which genes play key roles at the molecular level.

Expression of membrane transport genes in mutants To confirm the expression of membrane transport genes containing SNPs in salt-tolerant mutant lines, real-time RT-PCR analysis was carried out (Fig. 4). For this, two separate statistical analyses were used; one was for comparison of wild-type and mutants (double asterisks in Fig. 4 ), and the other was for comparison between untreated and salt-treated plants in the same line (single asterisks in Fig. 4). Salt treatment for two weeks increased the transcript levels of OsHKT6, OsNSCC2, OsHAK11 and OsSOS1 genes in wild-type. Similar to the expression in wild-type, OsNSCC2 transcripts in Till-III-255 and Till-III-114 lines were up-regulated under salt stress in comparison with the same lines without salt treatment. However, other lines such as Till-III-324, TillIII-142, Till-III-955 and Till-III-1224 showed no significant expression change for OsHKT6, OsNSCC2, OsHAK11 and OsSOS1 in comparison with their expression under normal conditions. The expression level of OsAKT1 in TillIII-19 was high with and without salt treatment compared to wild-type.

\section{DISCUSSION}

In this study, a TILLING population was generated in rice using gamma ray irradiation. The success of reverse genetic analysis in plants depends on induction of high mutation rates and efficient mutation analysis (Till et al., 2007). Mutation rates can be maximized by balancing the lethal dose of radiation and mutation frequency, which are inversely proportional. For gamma rays, survival rates rapidly decrease with 300 Gy and mutation frequency increases with increasing irradiation dose in rice (Yamaguchi et al., 2009). Additionally, treatments at doses of 200 Gy and 300 Gy revealed changes of gene expression and physiological parameters in Arabidopsis and rice (Hwang et al., 2014a). Therefore, we used two different irradiation doses, which were 200 Gy for a high survival ratio with slightly low mutation frequency, and 300 Gy for a low survival ratio with high mutation frequency. Mutation analysis is used to efficiently screen the locations or patterns of mutations that have been induced in individual seeds (Till et al., 2007). In this work we analyzed mutations with the TILLING method, using capillary electrophoresis. Two-dimensional capil- 
lary electrophoresis, an analytical approach constructed after much trial and error with the TILLING method, uses two different fluorescent dyes attached to each primer. Using two dyes helps to reduce the likelihood of problems occurring when a single fluorescent dye is used (Till et al., 2006).

The TILLING screening we performed on nine membrane transport genes permitted the calculation of the mutation density in gamma ray-irradiated mutant populations. The specific mutations caused by gamma radiation are different from those caused by ethylmethanesulfonate (EMS), a chemical mutagen often used in TILLING. The chemical primarily causes point mutations by making changes on alkyl radicals. In contrast, gamma radiation induces mutations by irradiating DNA and damaging the bases. Consequently, with irradiation, a variety of patterns, such as deletions and point mutations, are induced in regions of high doses or vulnerable DNA structures (Greene et al., 2003; Esnault et al., 2010). The sequences presented in the supplemental data have a variety of mutation patterns, including point mutations and deletions (Supplementary Fig. S1). The patterns of sequence variations were also diverse when compared to EMS treatment results. The rate of CG-AT variations induced by gamma radiation was approximately $10 \%$ lower than the $70-84 \%$ range that occurred in rice following EMS treatment (Table 2; Cooper et al., 2008). It may thus be possible to obtain more diverse phenotypes from mutations induced by gamma rays, and therefore more useful mutants and genomes.

We conclude that the function of these membrane transport genes is related to salt tolerance in rice. From the TILLING data in this study, nine mutant lines (Till-III-19 in the OsAKT1 gene, Till-III-324 in OsHKT6, Till-III-114, Till-III-142 and Till-III-255 in OsNSCC2, Till-III-955 in OsHAK11, Till-III-1028, Till-III-1224 and Till-III-1431 in OsSOS1) containing SNPs in coding regions of five membrane transport genes were identified (Fig. 2). Among these SNPs, seven caused amino acid changes (Till-III-19 in the OsAKT1 gene, Till-III-324 in OsHKT6, Till-III-114, Till-III-142 and Till-III-255 in OsNSCC2, Till-III-955 in OsHAK11, and Till-III-1224 in OsSOS1) in the five membrane transport genes (Fig. 3). These regions of amino acid change may influence salt tolerance of the mutant lines. To study changes of gene expression caused by these SNPs, we examined the expression patterns of membrane transport genes in the seven individual mutants using quantitative real-time RT-PCR (Fig. 4). In our gene expression analysis, OsAKT1 transcription was induced in Till-III-19 under non-treated conditions compared to wild-type (Fig. 4). Under salt stress, $\mathrm{Na}^{+}$competes with $\mathrm{K}^{+}$for uptake into roots. The $A K T$ gene was identified as encoding a high-affinity $\mathrm{K}^{+}$channel (Sentenac et al., 1992). A knockout Arabidopsis mutant of AKT1 (akt1-1) displayed similar salt sensitivity to wild-type, suggesting that this channel does not play a role in $\mathrm{Na}^{+}$ uptake (Spalding et al., 1999). The enhanced expression of $O s A K T 1$, which induces $\mathrm{K}^{+}$uptake and reduces $\mathrm{Na}^{+}$uptake, may increase $\mathrm{Na}^{+}$tolerance in the Till-III-19 mutant. HKT1 was identified as a putative regulator of $\mathrm{Na}^{+}$influx in plant roots. This conclusion was based on the capacity of $h k t 1$ mutants to suppress $\mathrm{Na}^{+}$accumulation (Rus et al., 2001). In this study, the expression level of OsHKT6 in Till-III-324 was significantly lower than that in a wild-type control after $\mathrm{NaCl}$ treatment (Fig. 4). Till-III-324 displayed a point mutation in the second exon of OsHKT6, which caused an amino acid substitution (Table 3). We suggest that this change affects the function of OsHKT6 in Till-III-324 and causes a decrease of $\mathrm{Na}^{+}$influx, which results in the salt tolerance of TillIII-324. Three mutant lines, Till-III-114, Till-III-142 and Till-III-255, contained SNPs in OsNSCC2, which may facilitate salt tolerance. OsNSCC2 functions to open the pore when the roots are exposed to a high ion concentration, particularly of $\mathrm{Mg}^{2+}$ and $\mathrm{Ca}^{2+}$. Opening the pore causes a large influx of $\mathrm{Ca}^{2+}$ and the plant experiences ion imbalances and salt stress (Bradshaw, 2005). It appears that the mutation of OsNSCC2 caused expression to change, and loss of this pore-opening function; thus, the three mutant lines (Till-III-114, Till-III-142 and TillIII-255) may avoid the toxicity of excess $\mathrm{Ca}^{2+}$. Also, the fact that the SNPs were at a common position (663) and phase $(\mathrm{C}-\mathrm{T})$ in the three lines is consistent with the idea that the pore-opening role of OsNSCC2 is critical. TILLING detected three individuals with SNPs in OsSOS1 (Table 2), but salt tolerance was detected in only one of the mutant lines, TILL-III-1224. This result indicates that the DNA sequence variations did not affect, or were not likely to affect, membrane transportation in the protein. Our results will help to develop salt-tolerant rice and to understand the role of salt tolerance-related genes.

\section{CONCLUSIONS}

Functional studies of plants conducted with complete genome sequences have aided our understanding of salttolerant genes and plant responses to environmental changes. In this study, some of the mutants screened by TILLING affected phenotypes and we identified mutations in membrane transport genes that affected the plant's tolerance to high-salt conditions. However, it must be kept in mind that salt tolerance results from complex interactions of many genes. Therefore, the detection of SNPs can be considered only the beginning of this venture. We plan a range of experiments on mutant lines to develop markers for the identification of salt-resistant genes. Further, we hope to create genomes that will be useful in agro-bioengineering.

This work was supported by grants from the Nuclear R\&D 
Program by the Ministry of Science, ICT and Future Planning, and the research program of KAERI, Republic of Korea.

\section{REFERENCES}

Bradshaw, H. D. (2005) Mutations in Cax1 produce phenotypes characteristic of plants tolerant to serpentine soils. New Phytol. 167, 81-88.

Chen, H., An, R., Tang, J. H., Cui, X. H., Hao, F. S., Chen, J., and Wang, X. -C. (2007) Over-expression of a vacuolar $\mathrm{Na}+/$ $\mathrm{H}+$ antiporter gene improves salt tolerance in an upland rice. Mol. Breeding 19, 215-225.

Cheong, M. S., and Yun, D. J. (2007) Salt-stress signaling. J. Plant Biol. 50, 148-155.

Chinnusamy, V., Zhu, Z., and Zhu, J. K. (2006) Salt stress signaling and mechanisms of plant salt tolerance. Genet. Eng. 27, 141-177.

Cooper, J. L., Till, B. J., Laport, R. G., Darlow, M. C., Kleffner, J. M., Jamai, A., El-Mellouki, T., Liu, S., Ritchie, R., Nielsen, N., et al. (2008) TILLING to detect induced mutations in soybean. BMC Plant Biol. 8, 9.

Demidchik, V., and Tester, M. (2002) Sodium fluxes through nonselective cation channels in the plasma membrane of protoplasts from Arabidopsis roots. Plant Physiol. 128, 379-387.

Dierking, E., and Bilyeu, K. (2009) New sources of soybean seed meal and oil composition traits identified through TILLING. BMC Plant Biol. 9, 89.

Esnault, M. A., Legue, F., and Chenal, C. (2010) Ionizing radiation: Advances in plant response. Environ. Exp. Bot. 68, 231-237.

Fang, Y., You, J., Xie, K., Xie, W., and Xiong, L. (2008) Systematic sequence analysis and identification of tissue-specific or stress-responsive genes of NAC transcription factor family in rice. Mol. Genet. Genomics 280, 547-563.

Flowers, T. J. (2004) Improving crop salt tolerance. J. Exp. Bot. 55, 307-319.

Fukuda, A., Nakamura, A., and Tanaka, Y. (1999) Molecular cloning and expression of the $\mathrm{Na}+/ \mathrm{H}+$ exchanger gene in Oryza sativa. Biochim. Biophys. Acta 1446, 149-155.

Fukuda, A., Nakamura, A., Tagiri, A., Tanaka, H., Miyao, A., Hirochika, H., and Tanaka, Y. (2004) Function, intracellular localization and the importance in salt tolerance of a vacuolar $\mathrm{Na}+/ \mathrm{H}+$ antiporter from rice. Plant Cell Physiol. 45, 146-159.

Fukuda, A., Nakamura, A., Hara, N., Toki, S., and Tanaka, Y. (2011) Molecular and functional analyses of rice NHX-type $\mathrm{Na}+/ \mathrm{H}+$ antiporter genes. Planta 233, 175-188.

Garciadeblás, B., Senn, M. E., Bañuelos, M. A., and RodríguezNavarro, A. (2003) Sodium transport and HKT transporters: the rice model. Plant J. 34, 788-801.

Greene, E. A., Codomo, C. A., Taylor, N. E., Henikoff, J. G., Till, B. J., Reynolds, S. H., Enns, L. C., Burtner, C., Johnson, J. E., Odden, A. R., Comai, L., and Henikoff, S. (2003) Spectrum of chemically induced mutations from a large-scale reversegenetic screen in Arabidopsis. Genetics 164, 731-740.

Henikoff, S., Till, B. J., and Comai, L. (2004) TILLING. Traditional mutagenesis meets functional genomics. Plant Physiol. 135, 630-636.

$\mathrm{Hu}$, S., Tao, H., Qian, Q., and Guo, L. (2012) Genetics and molecular breeding for salt-tolerance in rice. Rice Genomics Genet. 3, 39-49.

Hur, J., Jung, K. H., Lee, C. H., and An, G. (2004) Stress-inducible OsP5CS2 gene is essential for salt and cold tolerance in rice. Plant Sci. 167, 417-426.
Hussain, K., Nisar, M. F., Majeed, A., Nawaz, K., Bhatti, K. H., Afghan, S., Shahazad, A., and Zia-ul-Hussnian, S. (2010) What molecular mechanism is adapted by plants during salt stress tolerance? Afr. J. Biotechnol. 9, 416-422.

Hwang, J. E., Hwang, S. G., Kim, S. H., Lee, K. J., Jang, C. S., Kim, J. B., Kim, S. H., Ha, B.K., Ahn, J. W., Kang, S. Y., and Kim, D. S. (2014a) Transcriptome profiling in response to different types of ionizing radiation and identification of multiple radio marker genes in rice. Physiol. Plant. 150, 604-619.

Hwang, J. E., Ahn, J. W., Kwon, S. J., Kim, J. B., Kim, S. H., Kang, S. Y., and Kim, D. S. (2014b) Selection and molecular characterization of a high tocopherol accumulation rice mutant line induced by gamma irradiation. Mol Biol Rep. 41, 7671-7681.

Kamiya, T., Akahori, T., and Maeshima, M. (2005) Expression profile of the genes for rice cation/ $\mathrm{H}+$ exchanger family and functional analysis in yeast. Plant Cell Physiol. 46, $1735-1740$.

Kronzucker, H. J., and Britto, D. T. (2011) Sodium transport in plants: a critical review. New Phytol. 189, 54-81.

Lang, N. T., and Buu, B. C. (2008) Induction of salt tolerance in high yielding traditional rice cultivars through mutagenesis and somaclonal variation. SABRAO Journal of Breeding and Genetics 40, 141-146.

Martínez-Atienza, J., Jiang, X., Garciadeblas, B., Mendoza, I., Zhu, J. K., Pardo, J. M., and Quintero, F. J. (2007) Conservation of the salt overly sensitive pathway in rice. Plant Physiol. 143, 1001-1012.

Minoia, S., Petrozza, A., D’Onofrio, O., Piron, F., Mosca, G., Sozio, G., Cellini, F., Bendahmane, A., and Carriero, F. (2010) A new mutant genetic resource for tomato crop improvement by TILLING technology. BMC Res. Notes 3, 69 .

Møller, I. S., and Tester, M. (2007) Salinity tolerance of Arabidopsis: a good model for cereals? Trends Plant Sci. 12, 534-540.

Munns, R., and Tester, M. (2008) Mechanisms of salinity tolerance. Annu. Rev. Plant Biol. 59, 651-681.

Nakhoda, B., Leung, H., Mendioro, M. S., Mohammadi-nejad, G., and Ismail, A. M. (2012) Isolation, characterization, and field evaluation of rice (Oryza sativa L., Var. IR64) mutants with altered responses to salt stress. Field Crops Res. 127, 191-202.

Negrão, S., Courtois, B., Ahmadi, N., Abreu, I., Saibo, N., and Oliveira, M. M. (2011) Recent updates on salinity stress in rice: from physiological to molecular responses. Crit. Rev. Plant Sci. 30, 329-377.

Obata, T., Kitamoto, H. K., Nakamura, A., Fukuda, A., and Tanaka, Y. (2007) Rice shaker potassium channel OsKAT1 confers tolerance to salinity stress on yeast and rice cells. Plant Physiol. 144, 1978-1985.

Okada, T., Nakayama, H., Shinmyo, A., and Yoshida, K. (2008) Expression of $O s H A K$ genes encoding potassium ion transporters in rice. Plant Biotechnol. 25, 241-245.

Ren, Z. H., Gao, J. P., Li, L. G., Cai, X. L., Huang, W., Chao, D. Y., Zhu, M. Z., Wang, Z. Y., Luan, S., and Lin, H. X. (2005) A rice quantitative trait locus for salt tolerance encodes a sodium transporter. Nat. Genet. 37, 1141-1146.

Rus, A., Yokoi, S., Sharkhuu, A., Reddy, M., Lee, B. H., Matsumoto, T. K., Koiwa, H., Zhu, J. K., Bressan, R. A., and Hasegawa, P. M. (2001) AtHKT1 is a salt tolerance determinant that controls $\mathrm{Na}+$ entry into plant roots. Proc. Natl. Acad. Sci. USA 98, 14150-14155.

Sentenac, H., Bonneaud, N., Minet, M., Lacroute, F., Salmon, J. M., Gaymard, F., and Grignon, C. (1992) Cloning and expression in yeast of a plant potassium ion transport sys- 
tem. Science 256, 663-665.

Shi, H., Quintero, F. J., Pardo, J. M., and Zhu, J. K. (2002) The putative plasma membrane $\mathrm{Na}+/ \mathrm{H}+$ antiporter SOS1 controls long-distance $\mathrm{Na}+$ transport in plants. Plant Cell 14, 465-477.

Spalding, E. P., Hirsch, R. E., Lewis, D. R., Qi, Z., Sussman, M. R., and Lewis, B. D. (1999) Potassium uptake supporting plant growth in the absence of AKT channel activity. Inhibition by ammonium and stimulation by sodium. J. Gen. Physiol. 113, 909-918.

Suzuki, T., Eiguchi, M., Kumamaru, T., Satoh, H., Matsusaka, H., Moriguchi, K., Nagato, Y., and Kurata, N. (2008) MNUinduced mutant pools and high performance TILLING enable finding of any gene mutation in rice. Mol. Genet. Genomics 279, 213-223.

Till, B. J., Zerr, T., Comai, L., and Henikoff, S. (2006) A protocol for TILLING and Ecotilling in plants and animals. Nat. Protoc. 1, 2465-2477.
Till, B. J., Cooper, J., Tai, T. H., Colowit, P., Greene, E. G., Henikoff, S., and Comai, L. (2007) Discovery of chemically induced mutations in rice by TILLING. BMC Plant Biol. 7, 19.

Wan, X., Mo, A., Yang, L. L., and Li, L. (2011) Constiutive expression of a peanut ubiquitin-conjugating enzyme gene in Arabidopsis confers improved water-stress tolerance through regulation of stress-responsive gene expression. J. Biosci. Bioeng. 111, 478-484.

Yamada, N., Theerawitaya, C., Cha-um, S., Kirdmanee, C., and Takabe, T. (2014) Expression and functional analysis of putative vacuolar $\mathrm{Ca}^{2+}$-transporters (CAXs and ACAs) in roots of salt tolerant and sensitive rice cultivars. Protoplasma 251, 1067-1075.

Yamaguchi, H., Hase, Y., Tanaka, A., Shikazono, N., Degi, K., Shimizu, A., and Morishita, T. (2009) Mutagenic effects of ion beam irradiation on rice. Breed. Sci. 59, 169-177.

Yokoi, S., Bressan, R. A., and Hasegawa, P. M. (2002) Salt stress tolerance of plants. JIRCAS Working Report 23, 25-33. 